\title{
ECF 漂白工程の操業経験*
}

三菱製紙株式会社 八戸工場技術環境部 永 尾 伸 尚

\section{Operational Experience of ECF Bleaching}

Nobunao Nagao

Hachinohe Mill, Mitsubishi Paper Mill Limited

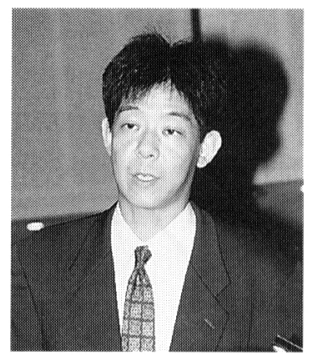

Oxygen bleaching sequence, efficient washing system and reinforced effluent treatment facilities, that had been introduced in Hachinohe mill of Mitsubishi Paper Mill since 1988, was allowed to reduce adsorbed organic halogen (AOX) with greatefficiency. However the gloval environmental demand intensely trends toward more and more reduction of emission or pollution. In view of the situation, the introduction of the elemental chlorine free (ECF) bleaching sequence to Hachinohe mill has been decided in 1999 .

In October 2000, No. 3 BKP-line, the product line of LBKP, was adapted for ECF bleaching sequence with the minimum conversion of existent bleaching facilities exept continuous cooker, washing facilities oxygen bleaching stage and so on. $\mathrm{D}_{0}(\mathrm{E} / \mathrm{O}) \mathrm{PD}$ sequence, in which the existent bleaching towers could be used, was selected for the ECF bleaching sequence on No. 3 BKP-line.

It was found that the brightness of oxygen-bleached pulp instead of the kappa number of oxygenbleached pulp dominated the bleaching efficiency on ECF bleaching sequence in contrast with the conventional chloline bleacing sequence. In the operation of ECF bleaching sequence, the prevention of scale and the reduction of bleaching chemicals have been carried out.

In this report, we describe the operational experience of ECF bleaching in this last year and discuss the main issues in ECF bleaching such as the influence of hexeneuronic acid in unbleachedpulp.

分類 $: K_{3}$ 酸素漂白, $W_{2}$ 漂白薬品

\section{1.はじめに}

三菱製紙八戸工場は 1988 年に酸素漂白法を導入し， 更にパルプ蒸解度の安定, 洗浄の強化, 排水処理設備 の増強等を実施し，排水中の AOX 大幅に削減した。 しかし, 今後環境負荷に対する要求は更に強くなって

*平成 13 年度年次大会講演（講演 No. C 5)
くることに鑑み, グローバルな視野からのより一層の 環境対策が必要と判断し，ECF の導人を決定した。

当工場の LBKP 製造設備のうち，3 BKP 系列につ いて, 既存設備を利用し, 連続蒸解釜・洗浄及び酸素 漂白工程等を全く改造することなく, 漂白設備の最小 限の改造によって 2000 年 10 月に ECF へ移行した。

漂白シーケンスには, 現行の漂白塔をそのまま利用 できる $\mathrm{D}_{0}(\mathrm{E} / \mathrm{O}) \mathrm{PD}_{1}$ シーケンスを採用した。ECF 漂 
白では，塭素漂白と比較してカッパー価よりも酸素漂 白後白色度が漂白性へ大きな影響を及ぼすことがわか った。また，スケールの防止，薬品使用量の減少等に 対する対策を実施してきた。本報告は，ECF 漂白の 導入後の約 1 年間にわたる操業経験及びへキセンウロ ン酸の影響に代表されるような今後の課題について述 べたものである。

\section{2. 設 備 概 要}

当社八户亡場は， 3 系列の $\mathrm{KP}$ 漂白設備を有してお り, BKP 製造能力の約半分を占める $3 \mathrm{BKP}$ 設備につ いて，ECF化を行った。図１に設備概要を示した。 連続蒸解釜及び酸素漂白を経て, 漂白工程に入る。漂 白設備は，全てディフューザータイプである4 塔から なり, シーケンスは従来の $(\mathrm{C} / \mathrm{D})(\mathrm{E} / \mathrm{O}) \mathrm{HD}$ から, こ れらの漂白タワーをそのまま使用できる $\mathrm{D}_{0}(\mathrm{E} / \mathrm{O}) \mathrm{PD}_{1}$ に変更し, 薬品添加設備や 3 塔の昇温設備の小改造, オンライン白色度計の増設等で対応した。

なお，二酸化塩素製造設備は従来の R $2 \mathrm{H}$ 法から $\mathrm{R}$ 8 法へ転向し, 当丁場の全 BKP 系列の ECF 化に対応 可能である国内最大の $20 \mathrm{~T} /$ 日製造設備を新設した。 特に問題はなく予定通り立ち上げることができ, 計画 性能を発揮した。

\section{3. $\mathrm{ECF} へ$ の切り替え}

\subsection{1 塔 $\mathrm{C} / \mathrm{D}$ 段から $\mathrm{D}$ 段への切替え}

2000 年 8 月の R 8 設備の立ち上げとともに, 3 BKP の $\mathrm{C} / \mathrm{D}$ 段の D 置換摔を段階的にアップさせ, 紙品質 や操業性に問題のないことを確認しながら D 100\%を

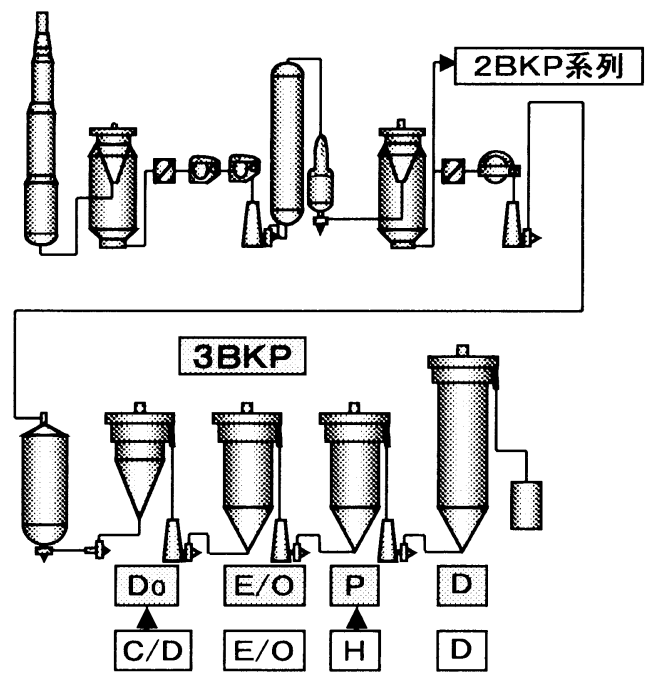

図 1 連釜系列フロー龱
達成した $\left[\mathrm{D}_{0}(\mathrm{E} / \mathrm{O}) \mathrm{HD}_{1}\right]$ 。

\subsection{3 塔 $\mathrm{H}$ 段から $\mathrm{P}$ 段への切替え}

さらに, 3 塔の $\mathrm{H}$ 段から $\mathrm{P}$ 段への移行については, まず 2 塔 $\mathrm{E} / \mathrm{O}$ 段に過酸化水素を添加し, 3 塔 $\mathrm{H}$ 段の負 荷を下げた状態で $\mathrm{P}$ 段へ切替えた $\left[\mathrm{D}_{0}(\mathrm{E} / \mathrm{OP}) \mathrm{PD}_{1}\right]$ 。 このシーケンスで数回の短時間テストを実施し, 紙品 質，操業性に問題のないことを確認しながら慎重に切 り替えを進めた。その後, 2 塔と 3 塔の過酸化水素の 添加比率を調整しながら, 最終的に $\left[\mathrm{D}_{0}(\mathrm{E} / \mathrm{O}) \mathrm{PD}_{1}\right]$ シーケンスを達成した。また, 過酸化水素の総使用量 を比較した場合，(E/OP) P と (E/O)P とでは, 後者 の方が若干少なく漂白効率が良いことがわかった。な 押，過酸化水素漂白を阻害する $\mathrm{Mn}, \mathrm{Fe}$ 等の重金属 イオン濃度については, 分析した結果特に問題のない レベルであった。なお，各段の主な反応条件を表 1 に 示した。

\subsection{ECF 化の結果}

\subsection{1 パルプ品質}

ECF 化を完了した結果，パルプ及び紙の諸物性, また紙の印刷適性など特に問題ないことを確認した。 表 2 にCF パルプと従来のパルプの品質を示した。

表 1 反応条件

\begin{tabular}{lrrrr}
\hline & 1 塔 & 2 塔 & 3 塔 & 4 塔 \\
\cline { 2 - 5 } & $\mathrm{D}_{0}$ & $\mathrm{E} / \mathrm{O}$ & \multicolumn{1}{c}{$\mathrm{P}$} & \multicolumn{1}{c}{$\mathrm{D}_{1}$} \\
\hline 温度 $\left({ }^{\circ} \mathrm{C}\right)$ & 55 & 55 & 75 & 75 \\
時間 $($ 分 $)$ & 30 & 80 & 80 & 120 \\
濃度 $(\%)$ & 10 & 10 & 10 & 10 \\
\hline
\end{tabular}

表 2 パルプ品質

\begin{tabular}{ll|r|r}
\hline & ECF & 従来 \\
\hline $\mathrm{CSF}(\mathrm{ml})$ & 400 & 400 \\
\hline 比引裂度 $\left(\mathrm{mN} / \mathrm{g} / \mathrm{m}^{2}\right)$ & 10.3 & 10.5 \\
\hline 裂断長 $\quad(\mathrm{km})$ & 8.4 & 8.5 \\
\hline 耐折度 $($ 回 $)$ & 58 & 55 \\
\hline 内部結合強度 $(\mathrm{mJ})$ & 238 & 237 \\
\hline 白色度 $(\mathrm{dry} \%)$ & 86.3 & 86.2 \\
\hline 粘度 $\quad(\mathrm{mPa} \cdot \mathrm{s})$ & 32 & 30 \\
\hline 夾雑物 $\left(\mathrm{mm}{ }^{2} / 100 \mathrm{~g}\right)$ & 0.5 & 0.6 \\
\hline パルプ中の \\
有機塩素化合物 $(\mathrm{ppm})$ & 140 & 350 \\
\hline
\end{tabular}


一般物性については特に変化なかった。なお， ECF の特徵として, パルプ中の有機塩素化合物量が 350 $\mathrm{ppm}$ から $140 \mathrm{ppm}$ へ大幅に低減したことが挙げられ る。

\subsection{2 環境負荷量の変化}

図 2 に, $3 \mathrm{BKP}$ 工程から排出される環境負荷量の 変化を示した。従来の漂白法と比較して COD は同等 か若干の減少, 色度は約 $60 \%$ 減, AOX は約 $65 \%$ 減, またクロロホルムについては, クロロホルムの大半を 排出する塩素段及び八イポ段がなくなることによって, ほぼ発生はなくなり, 環境負荷量は計画通り大幅な低 減を達成した。

\section{4. 操業における問題点}

約 1 年間にわたる操業の中で, 漂白薬品原単位とス ケール付着の 2 つのきな問題点について以下に示し た。

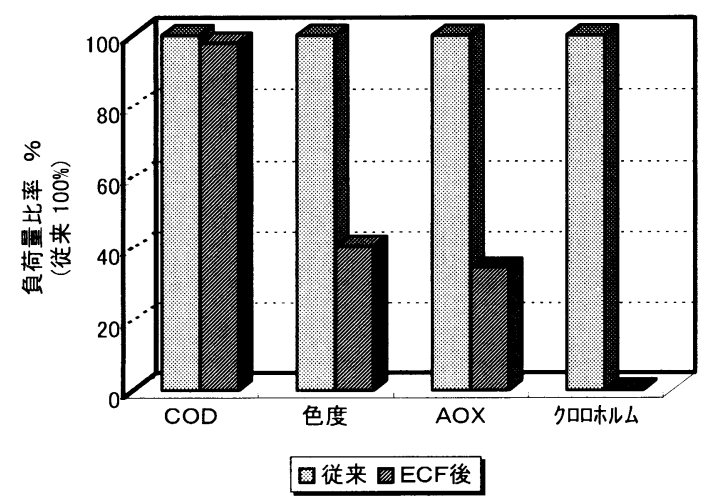

図 $23 \mathrm{BKP}$ 工程排出環境負荷量の変化

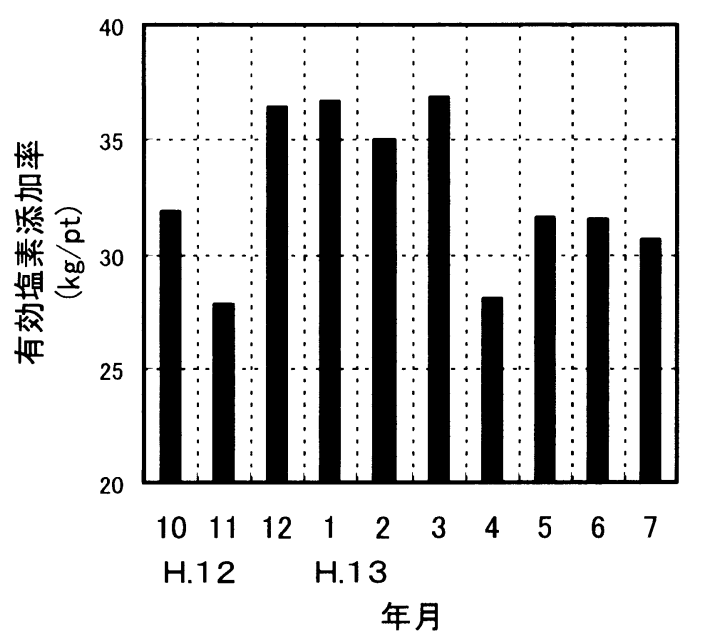

図 $3 \mathrm{ECF}$ 漂白有効塩素添加量の推移 (月平均)

\section{1 漂白薬品原単位}

\subsection{1 漂白有効塩素添加量の推移}

H 12.10〜H 13.7 に打ける漂白に要した有効塩素添 加量（月平均）を図 3 に示した。約 $27 \sim 37 \mathrm{~kg} / \mathrm{pt}$ と 約 $10 \mathrm{~kg} / \mathrm{pt}$ の差があり，このばらつきは非常に大き いと言える。

\subsection{2 酸素漂白後の白色度の影響}

従来の漂白法ではカッパー価を重視しており, 通常 は漂白工程の前段階での管理指標として蒸解後及び酸 素漂白後のカッパー価を用いてきた。しかし， ECF 漂白においては, 後述する様に酸素漂白後のカッパー 価とともに, 白色度もまた重要な指標であることを確 認した。図 4-1 及び図 4-2にD。段の漂白性について のラボテスト結果を示した。なお，ここでは $D_{0}$ 段の みについて示したが， $\mathrm{D}_{0}$ 段の白色度が同等であれば, 後段の薬品使用量はほぼ一定となることを確認してお り, $\mathrm{D}_{0}$ 段の薬品原単位の変動がそのまま全体の変動 に反映していると考えている。

まず，図 4-1に，実機における酸素漂向後のパルプ に扔いて, カッパー価の差が 1.3 ポイントと大きいが 白色度は同等であるものについて示した。その結果, 初期白色度が同等である場合には同じ、酸化塩素使用

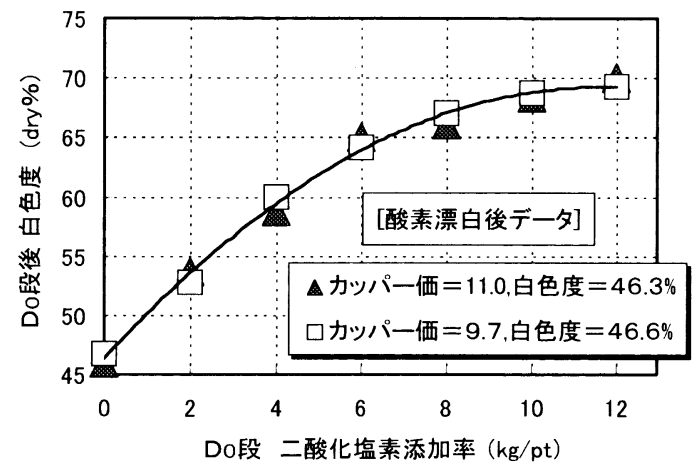

図 4-1 Do 段に扩ける漂向性（ラボ）

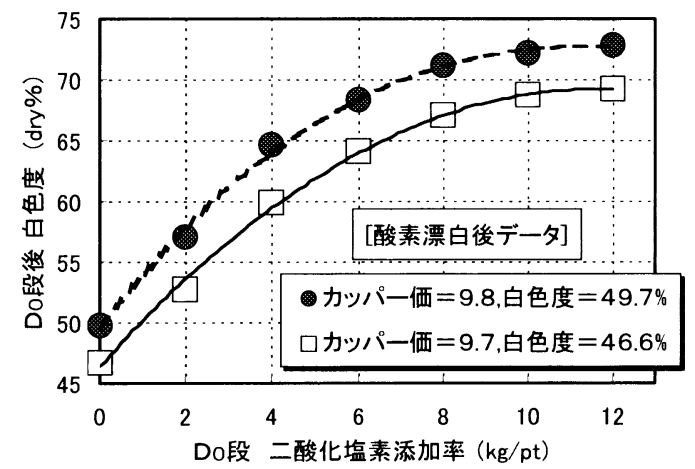

図 4-2 Do段における漂白性（ラボ） 
量で同等の $\mathrm{D}_{1}$ 段白色度を得ることができた。

次に, 図 4-2 にカッパー価は同等であるが白色度が 約 3 ポイントの差があるものについて示した。その結 果, 同じ二酸化塩素添加量において, 初期白色度の差 がそのまま維持される形となり, 初期白色度が低いと $\mathrm{D}_{0}$ 段白色度が低いことがわかる。これらから, 酸素 漂白後パルプにおいては, カッパー価と比較して白色 度の方がより大きく漂白薬品原単位に影響を及ぼして いると言える。

図 5 に酸素漂白後の白色度と有効塩素添加量の関係 を示したが, 両者は強い相関関係にあり, 白色度が大 きく影響していることが示された。ここで, 白色度に 5 ポイントの差があると有効塩素添加量は約 $10 \mathrm{~kg} / \mathrm{pt}$ も異なってくる。

また, 従来は $\mathrm{E} / \mathrm{O}$ 段後のカッパー価が高くなると 後段の漂白性が悪化することから, これを 1 3 回/日 の頻度で測定を行い管理していたが，ECF 漂白では D 段出口白色度が同一である場合には，例えば $\mathrm{E} / \mathrm{O}$ 段後のカッパー価が 2 ポイント程度変動した場合でも 後段の漂白性には特に変化はなかったことから, E/O 段後カッパー価の測定管理を不要とした。

\section{1 .3 酸素漂白後のカッパー価と白色度の関係}

従来は酸素漂白後の白色度については特に重視して いなかったが, 前述の通り, 白色度が非常に重要であ ることを確認した。そこで, まず白色度のばらつきに ついて調查を行った。図6-1に, 実機における酸素漂 白後のカッパー価と白色度の関係を示した。カッパー 価と白色度の間には負の相関があり, カッパー価が上 昇すると色色度は低下する傾向があることは周知のこ とであり，基本的にはカッパー価管理でも良いと言え る。

しかし，同一カッパー価に扔いて白色度は約 5 ポイ ントのばらつきがあり,この色色度の 5 ポイントの差 は前述した通り, 四 5 より有効塩素添加量約 $10 \mathrm{~kg} / \mathrm{pt}$

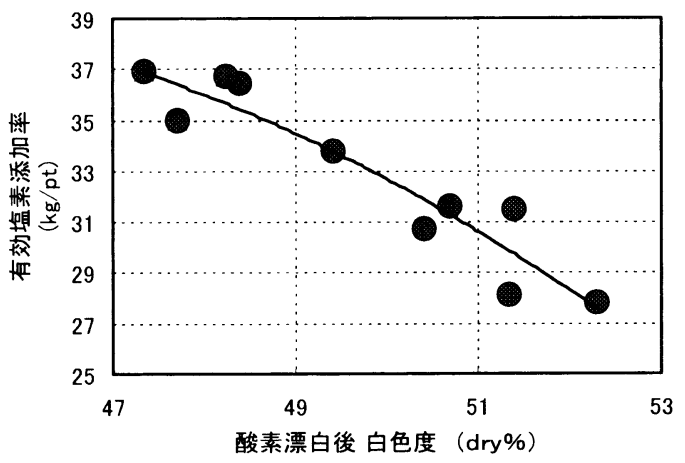

図 5 酸素漂白後白色度と有効塩素添加率（実機）
の差となる。

そこで，このばらつきの要因を究明することが漂白 性の向上に結びつくと考えた。

\section{1 .4 洗浄度の影響}

そこで, 図 6-1について洗浄度に着目して層別した 結果を図 6-2に示した。この図は，酸素漂白前の洗浄 機の脱水シート搾水中の COD 值を洗浄工程の洗浄度 の代表とし，その值によって酸素漂白後のカッパー価 と白色度の関係を層別したものである。この図から， 同一カッパー価で比較した場合，COD 值が低い方， 即ち洗浄度が良い方が白色度が約 2 ポイント高くなる 傾向が見られた。

これらの結果より，洗浄度の向上は，従来の漂白法 においても重要ではあるが，ECF 漂白法については， これまでにも述べた様に白色度の影響を受けやすいた め, より重要なポイントになると考えている。

\subsection{5 樹種別白色度}

次に, 酸素漂白後の白色度のばらつきの要因として 樹種の違いについて調査を行った。当工場の連釜系列

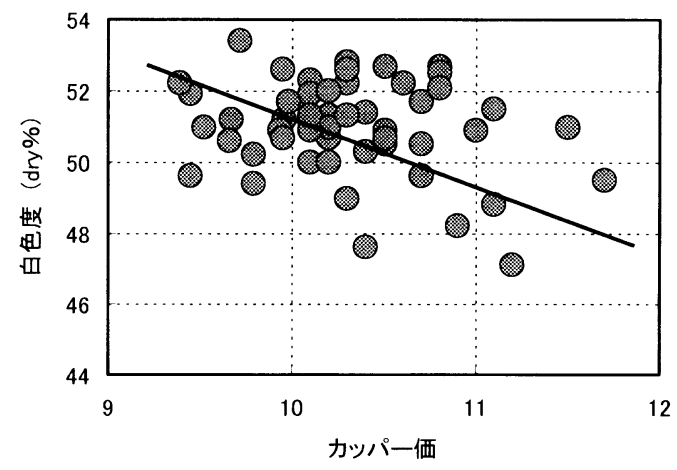

図 6-1 酸素漂白後カッパー価と白色度 (実機)

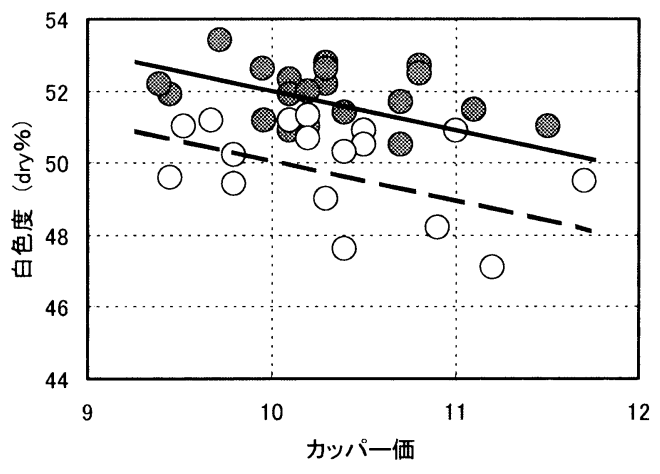

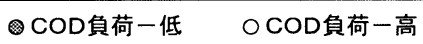

図 6-2 酸素漂白後カッパー価と白色度（実機） 一洗浄度の影響— 
は主体チップとしてユーカリ材を用いているが，産地 別に分けて通常 3〜5 種類のチップを配合して使用し ている。ECF 漂白となり, 前述の通り白色度管理が 重要となったため, 樹種別の蒸解後の白色度デー夕を 採取した。その結果を図７に示した。蒸解後の白色度 のレベルは樹種によって異なり, 同一カッパー価にお いて白色度は最大約 7 ポイント程度異なることがわか った。この白色度の違いが漂白性へ影響し, 特に ECF 漂白の場合に顕著になると考えられる。

そこで, ECFへの移行に伴い, チップの評価項目 に新しく蒸解後の白色度を追加した。実機における ECF 漂白性を使用樹種及び配合率から推定を行う場 合には，その白色度が重要な要素となった。

なお，図 6-1 で示した実機での同一カッパー価にお ける白色度のばらつきのうち, 通常操業においても 2 〜 3 ポイントについては樹種による差で説明すること ができた。

\section{1 .6 へキセンウロン酸}

カッパー価として検出される構成成分として，へキ センゥロン酸（以下，HexA）の存在が認められてお り, 今後, HexAの挙動の解明が重要なポイントと考 えているが, 白色度のばらつきの要因として HexA に着目し，調査を行った。

まず，図 8 に樹種別にラボ蒸解を行い, 蒸解後のカ ッパー価をHexAに由来する部分とリグニンに由来 する部分に分けた結果を示した。なお，ここでは $\mathrm{pH}$ $3.5,110^{\circ} \mathrm{C}, 2$ 時間の条件で酸処理を行い, 処理後の カッパー価を分析し，その值をリグニン由来のカッパ 一価, カッパー価低減量をHexA 由来のカッパー価 とした。HexA は蒸解過程で生成することや樹種によ って生成量が異なることなど報告されているが実際に 当工場で使用しているユーカリ材についても HexA

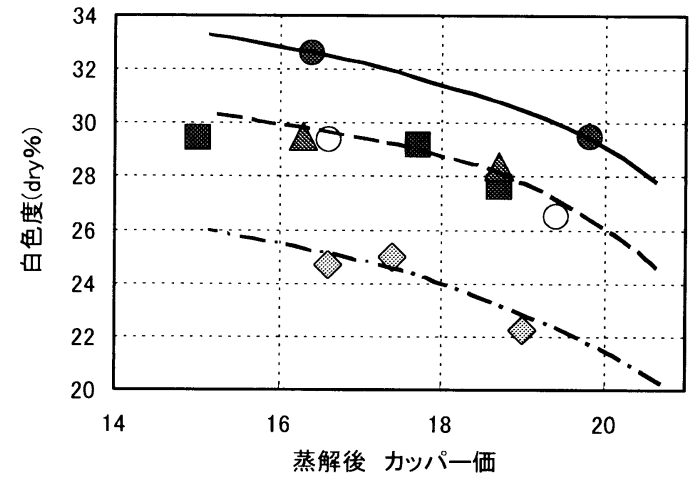

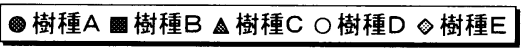

図 7 樹種別蒸解後カッパー価と白色度 (ラボ)
由来のカッパー価が蒸解後カッパー価に占める割合が 30～50\% と大きなばらつきがあることが分かった。

図 9 に，実機における酸素漂白後パルプを前述と同 様に酸処理し, 白色度とカッパー洒, 白色度と HexA 由来及びリグニン由来のカッパー価との関係を示した カッパー価と白色度の関係は負相関であり，相関係数 は 0.53 であった。これと比較してリグニン由来のカ ッパー価と白色度の相関係数は 0.61 と高くなり, 白 色度と HexA 由来のカッパー価の間には相関が見ら れなかった。

これらから，酸素漂白後の白色度にはリグニンが大 きく影響しており, HexA は寄与しないと考えられる しかし, HexA も二酸化塩素などの漂白薬品を消費す ることから, 蒸解条件やその他操業条件がHexA 生 成量に及ぼす影響を調查中である。

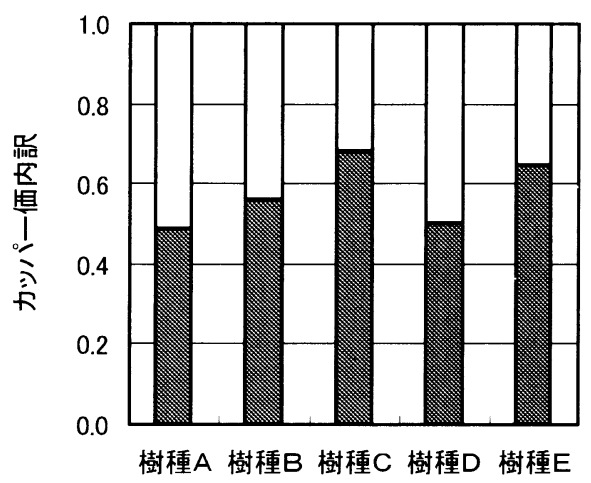

四リグニン由来カッパー価ロHexA由来カッパー価

図 8 樹種別蒸解後カッパー価内訳（ラボ）
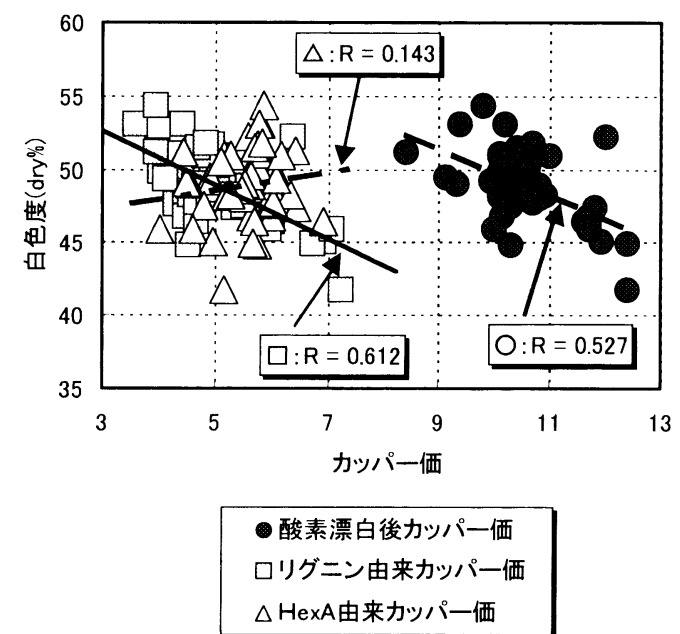

図 9 酵素漂白後カッパー価と白色度 (実機) 


\section{2 スケール防止}

\subsection{1 スケールの発生}

従来の漂白では, 定期的にディフューザースクリー ンを薬品洗浄することによって, 特に大きな問題もな く操業を行ってきた。しかし， $\mathrm{D}_{1}$ 段の抽出白水流量 が大幅に低下し，大きな問題となった。スケール分析 の結果，推測した通りシュウ酸カルシウムであった。

ECF は従来の漂白と比較して， $\mathrm{D}_{0}$ 段の適正 $\mathrm{pH}$ が 高くなるため，主にチップから持ち込まれるカルシウ ムイオンの系外への排出量が減少すること, また, 操 業条件がシュウ酸カルシウムスケールの発生しやすい $\mathrm{pH}$ 域にあたることなどスケール生成にとっては不利 な条件と考えられる。

\subsection{2 スケール防止}

スケール対策として， $\mathrm{D}_{0}$ 段の $\mathrm{pH}$ を反応における 適正 $\mathrm{pH}$ から 1 ポイント下げ，溶解カルシウムイオン を増加させることにより，その系外への排出量の増加 を試みた。しかし，あまり効果を見せず， $D_{1}$ 段洗浄 スクリーンにスケール付着は進行していき，抽出不良 により操業に大きな支障をきたした。

また， $\mathrm{D}_{10}$ 段の $\mathrm{pH}$ 調整として使用している硫酸添 加量が増えることから，洗浄スクリーンへの硫酸バリ ウムスケールの付着も懸念されたため, スケールコン トロール剤の使用を検討することとした。

\subsection{3 スケールコントロール剂の使用}

スケールコントロール率の選定に際しては，ポリマ 一系コントロール剤とホスホン酸系コントロール剂の 2 種類の薬品についてテストを行うことにした。

添加場所は $\mathrm{D}_{1}$ 段へのフィードラインとした。評価 方法は白水中のシュウ酸及びカルシウム量を分析する とともに，テストサンプルとして漂白後の精選工程の 白水ラインに清浄な SUS 製ワイヤーネットを浸し, そのワイヤーネットへのスケール付着具合を定期的に 顕微鏡で観察する方法を用いた。

テストの結果，スケールコントロール剤の効果を確 認し，特にホスホン酸系コントロール剂は，これまで
パルプ製造工程では使用実績がないとのことであった が，十分な効果が確認された。現在では，後者のホス ホン酸系のスケールコントロール剤を常時添加してい る。さらに他種のコントロール剤についても検討を進 め，より有効なものを選定していく。

\section{5. ま と め}

以上をまとめると次の通りである。

\section{$5.1 \mathrm{ECF}$ 化の結果}

1）品質については，パルプ，紙の諸物性及び紙の 印刷適性とも特に問題ない。

2）環境負荷量は計画通り AOX，クロロホルム排 出量の大幅な低減を達成した。

\section{$5.2 \mathrm{ECF}$ 操業上における問題点}

1) ECF 漂白薬品原単位

(1)従来の塩素漂白と比較して酸素漂白後の白色度の 影響をより顕著に受けやすい。

(2)酸素漂白後の同一カッパー価における白色度のば らつきが大きく, 樹種, 洗浄度及びカッパー価構 成成分比率等が影響している。

\section{2）スケール付着}

(1) $\mathrm{D}_{1}$ 段スクリーンへのシュウ酸カルシウムの付着。 (2)ホスホン酸系スケールコントロール剂を使用開始。

\section{6. 今後の課題}

酸素漂白後白色度のばらつきの要因の究明とそれに 対する対策を行い，白色度を向上させることが ECF の最適化にとって重要であり, 洗浄度向上がポイント と捉えている。また，カッパー価として検出される HexAについても生成及び分解除去等に関する解明が 今後の課題となるであろう。

スケール防止については，より効果を発揮するコン トロール剤の選定と効率の良い使用方法の確立も必要 となるが，白水循環や $\mathrm{pH}$ 条件など漂白条件の見直し による根本的な対策も検討していきたい。 